\title{
Cow Side and Laboratory Tests for Diagnosis of Subclinical Mastitis in Cows
}

\author{
Aruna Maramulla ${ }^{1 *}$, Ambica Gadige ${ }^{1}$, Lakshmi Kosapati ${ }^{2}$, Swathi Bommu $^{3}$, \\ Padmaja Katta ${ }^{4}$ and Ramesh Keshamoni ${ }^{1}$ \\ ${ }^{1}$ Department of Veterinary Medicine, ${ }^{3}$ Department of Veterinary Physiology and \\ Biochemistry, College of Veterinary Science, Rajendranagar, \\ Hyderabad - 500 030, Telangana, India \\ ${ }^{2}$ Department of Veterinary medicine, College of Veterinary Science, Korutla - 505326 , \\ Jagtial District, Telangana, India \\ ${ }^{4}$ Department of Veterinary Medicine and Animal Husbandry Polytechnic, Mahaboobnagar - \\ 509 001, Telangana, India \\ *Corresponding author
}

\section{Keywords}

Sub clinical mastitis, Diagnosis, California mastitis test, Somatic cell count, Cultural examination

\section{Article Info}

Accepted:

22 October 2019

Available Online:

10 November 2019
A total of 492 quarter milk samples from 123 animals were screened with CMT and among these, 366 quarter milk samples were negative for CMT reaction whereas, 40, 54 and 32 quarter milk samples showed + , ++ and +++ grades of CMT reactions with $74.39 \%, 8.13 \%, 10.98 \%$ and $6.50 \%$, respectively. 492 milk samples were also analyzed for SCC and out of these 357, 33, 41, 18, 29 and 14 samples were showing SCC in the range of <1 lakh, 1-2 lakhs, 2-3 lakhs, 3-4 lakhs, 4-5 lakhs and 5-6 lakhs, respectively. Out of 492 quarter milk samples, 164 were found culturally positive and among these 87 $(53.05 \%)$ positive for Staphylococcus spp., 22 (13.42\%) for Streptococcus spp., 28 (17.07\%) for Escherichia coli, 4 (2.44\%) for Klebsiella spp., 5 (3.05\%) for Staphylococcus spp. + Streptococcus spp., 5 (3.05\%) for Escherichia coli + Streptococcus spp., and 13 (7.93\%) for Escherichia coli + Staphylococcus spp. Comparative study of diagnostic tests was conducted between CMT, SCC and cultural examination and found animal wise incidence as $63.42,66.67$ and $73.98 \%$ respectively, whereas quarter wise incidence was 25.61, 27.44 and 33.33\%, respectively. Among the CMT negative and 1+, 2+ and 3+ grades CMT positive samples, culturally positive samples were 54, 31, 48 and 31 with $14.75 \%, 77.50 \%, 88.89 \%$ and $96.86 \%$, respectively. Whereas, culturally positive cases with regard to SCC of <1 lakh, 1-2 lakhs, 2-3 lakhs, 3-4 lakhs, 4-5 lakhs and 5-6 lakhs were $36,28,39,18,29$ and 14 with $10.08,84.85,95.12,100.00,100.00$ and 100.00 percent, respectively. The percent accuracy of CMT and SCC taking cultural examination as standard was 85.77 and 89.63 percent, whereas false positive are 12.70 and 11.11 percent and false negative results are 14.75 and 10.08 percent respectively. Sensitivity of CMT and SCC considering cultural examination as standard was reported as 67.07 and 76.92 percent, respectively and with specificity of 95.12 and 95.54 percent and predictive value of positive test as 87.30 and 88.89 percent, respectively. 


\section{Introduction}

Mastitis is the inflammation of mammary gland and is a complex disease causing major economic loss in dairy industry throughout the world. Examination of the association between milk yield and disease in many dairy cows found that higher milk yield was not a factor for any disease except mastitis (Grohn et al. 1995). The quickest and simplest way to identify the intramammary infections (IMIs) in dairy cows is using defined parameters within either SCC (Somatic Cell Count) or CMT (California Mastitis Test) scores.

The CMT is a rapid and inexpensive test to indirectly determine the somatic cell concentration in milk (Midleton et al., 2004) and is a practical and easy method for demonstrating IMIs by testing milk samples on-farm (Dingwell et al., 2003). Somatic cells are always present in milk and they increase due to mammary gland infections. SCC in healthy cow's milk is between 50,000 and 100,000 cells $/ \mathrm{ml}$. If the SCC exceeds 200,000 cells $/ \mathrm{mL}$, it is considered unhealthy for consumers. High SCC in milk reduces the quality of both milk and dairy products, and also affects milk shelf-life and flavor (Skrzypek et al., 2004). The greater the SCC increase $>10000 / \mathrm{ml}$ increases the production loss (Halasa et al., 2007). The prominent bacteria responsible for causing mastitis include both Gram-positive and Gramnegative bacteria like Staphylococci, Streptococci, Escherichia coli and Klebsiella pneumonia (Contreras and Rodríguez 2011).

\section{Materials and Methods}

\section{Animals (Patients)}

The study was carried out on cases of subclinical mastitis in cows from different dairy farms and individual holdings in and around the Hyderabad during the period from
January 2019 to June 2019. The cows in lactation below three months after calving were taken as in their early lactation; those in between three to six months were taken as in their mid lactation and above six months were taken as in their late lactation.

The cows in mid lactation were selected for present study. The data pertaining to age, breed, lactation number, stage of lactation, method of milking was collected. The affected animals were randomly selected into two uniform groups i.e., group I and group II, each containing ten animals. A group of ten healthy animals were also examined and the milk samples were taken for detailed analysis.

\section{California Mastitis Test (CMT)}

The milk samples were subjected to CMT as per the procedure given by Schalm and Noorlander (1957) using a modified CMT reagent (Sharma and Rajani, 1969). The principle of this test is that the detergent causes rupture of somatic cells when added to a milk sample due to which DNA and other cell contents are released. Released DNA from ruptured cells unites to form a gel, the consistency of which depends upon the number of somatic cells.

\section{Procedure}

One strip of milk was drawn into a plastic paddle with four cups (designed by GlaxoIndia) from each quarter. To this, $1 \mathrm{ml}$ of the CMT reagent was added.

The contents were then mixed by gentle stirring for 15 to $20 \mathrm{sec}$. Based on the reaction, the results were graded as per Schalm et al., (1971) as negative, 1+ (there is precipitate but no gel formation), 2+ (the precipitate thickens and forms gel towards the centre of the paddle) and $3+$ (distinct gel that adheres to the bottom of the paddle). 


\section{Somatic cell count (SCC)}

Total somatic cell count was estimated using Eko milk scan somatic cells analyzer supplied by M/s Eon Traders, as per the manufacturer's instructions. The values obtained were expressed as $\times 10^{3}$ cells $/ \mathrm{ml}$ of milk.

The milk samples containing SCC range of 01 lakh cells/ml were considered negative (Hadrich et al., 2018), 1-6 lakh cells/ml as sub clinically infected and $>6$ lakh cells $/ \mathrm{ml}$ as positive for clinical mastitis.

\section{Cultural examination of milk samples}

The milk samples from the quarters were collected by following aseptic precautions into sterile sample collecting tubes and then subjected to bacteriological examination for isolation of etiological agents.

\section{Preparation of glassware}

All the glassware used in this study were dipped into Sulphuric acid for 24 hours, washed under running tap water, again soaked in Teepol solution for 24 hours, cleaned with brush and washed under running water.

The glassware were then rinsed in glass distilled water and dried at $50^{\circ} \mathrm{C}$, carefully packed and sterilized at $160^{\circ} \mathrm{C}$ for one and half hours in hot air oven. The cleaned and sterilized glassware were then used for cultural and biochemical studies.

\section{Preparation of media}

All the media obtained as dehydrated powders were rehydrated as per the manufacturer's instructions by adding distilled water to a known quantity of media, mixed and boiled to dissolve. Then the media were sterilized by autoclaving at $121^{\circ} \mathrm{c}, 15 \mathrm{lb}$. pressure for 15 minutes. The blood agar medium and
Edwards's medium were prepared in laboratory as per procedure given by Quinn $e t$ al., (1999).

\section{Collection of milk}

The udder and teats were cleaned with water and dried with individual paper towels. The teat orifice and the skin around the teat were wiped with cotton soaked in 70 per cent alcohol.

In sterile sample collecting tubes about $10 \mathrm{ml}$ of foremilk was collected duly following aseptic precautions. Care was taken to avoid any type of contamination. The samples were brought to laboratory within 3 hours after collection in cold chain.

\section{Isolation of bacteria}

Milk samples were inoculated into the nutrient broth and incubated at $37^{\circ} \mathrm{C}$ for 24 hours aerobically and a loopful of broth culture was streaked on agar media plates. The plates were incubated at $37^{\circ} \mathrm{C}$ for 24 to 48 hours. If 5 or more colony forming units of recognized bacteria were present, then the quarter was said to be infected (Robinson et al., 1988).

For isolation of fungi and yeast, milk samples were inoculated into Sabouraud dextrose broth and incubated at $37^{\circ} \mathrm{C}$ up to 5 days aerobically.

\section{Identification of bacteria}

Primary identification of bacteria was done based on colony morphology, type of hemolysis and Gram's staining and pure cultures were identified up to genus level as per the Bergey's Manual of Determinative Bacteriology (Buchanan and Gibbons, 1974). The below tests were done on a 24-48-hour old pure culture for the identification of bacteria. 


\section{Gram's staining}

For identification of gram positive and gramnegative bacteria staining of bacterial smears was done by gram's stain by mixing a 24-hour old colony with sterile saline on a microscopic slide.

The smear was then air dried, heat fixed over flame and then stained with gram's stain and examined under oil immersion.

\section{Motility test}

This was done by hanging drop method for detection of motility. A drop of 6-8-hour old broth culture was placed on a cover slip and the cover slip was then placed upside down on a microscopic slide containing a circular depression. The motility of the bacteria was examined under high power.

\section{Bio chemical tests}

For confirmation of bacteria the following biochemical tests were under taken as per standard procedure given by Cruickshank et al., (1975).

\section{Catalase activity}

This was tested by placing a loopful of bacterial colony on microscopic slide and then mixed with a drop of 3 per cent hydrogen peroxide solution. Production of gas bubbles after few seconds indicated the bacteria as catalase positive.

\section{Haemolysin test}

Blood agar plates containing 5-10 per cent defibrinated sheep blood were used for this test. The bacteria were grown on these plates and the type of haemolysis was recorded after 24 hours of incubation at $37^{\circ} \mathrm{C}$.

\section{Indole test}

By using 48-hour old culture in peptone water, gram negative bacteria were tested for Indole production. $0.5 \mathrm{ml}$ of Kovac's Indole reagent was slowly rundown the sides of the culture tube and formation of a pink or deep red color reagent layer was taken as positive.

\section{Methyl Red (MR) test}

MR-VP medium was used for this test. The organisms were grown in this medium at $37^{\circ} \mathrm{C}$ for 48 hours. Then to this 48 -hour old culture, about 5 drops of methyl red reagent was added. Development of red color was taken as positive reaction while development of yellow color was taken as negative reaction.

\section{Voges -Proskauer (VP) test}

This test was done to detect the acetone production by the organisms by growing in MR-VP medium at $37^{\circ} \mathrm{C}$ for 48 hours. To this culture, about $0.6 \mathrm{ml}$ of 5 percent Alpha Naphthol reagent was added followed by 0.2 $\mathrm{ml}$ of 40 per cent potassium hydroxide solution.

The tubes were kept for 30 minutes after mixing the above reagents and watched for development of a bright pink or magenta color which was considered as a positive reaction.

\section{Citrate utilization test}

The citrate utilization by bacteria was tested on Simon's citrate agar slants. A light suspension of the test organism in sterile saline was inoculated in linear streaks on citrate agar slants. The slants were then incubated at $37^{\circ} \mathrm{C}$ and observed for 5 days. Growth associated with a color change to Prussian blue from green color was regarded as a positive test. 


\section{Results and Discussion}

\section{California mastitis test}

In present investigation out of 492 quarter milk samples from 123 animals subjected for CMT, 366 (74.39\%) quarters were negative and remaining 40, 54 and 32 quarters showed ,+++ and +++ reaction with $8.13,10.98,6.50$ percent, respectively. Similarly, Kasikci et al., (2012) reported CMT +, ++ and +++ reaction in $258(66.85 \%), 85(22.02 \%)$ and 43 $(11.13 \%)$ out of 386 quarter milk samples.

\section{Somatic cell count}

A total of 492 milk samples were analyzed for SCC and out of these 357, 33, 41, 18, 29 and 14 samples were showing SCC in the range of <1 lakh, 1-2 lakhs, 2-3 lakhs, 3-4 lakhs, 4-5 lakhs and 5-6 lakhs, respectively

\section{Cultural examination}

Cultural examination was conducted to know the specific etiological agent and out of 492 samples tested, 87 (53.05\%) were positive for most prevalent Gram positive Staphylococcus spp., followed by 28 samples $(17.07 \%)$ for Gram negative Coco bacillus i.e., Escherichia coli, $22(13.42 \%)$ for Gram positive Streptococcus spp., and $4(2.44 \%)$ were positive for Klebsiella spp. Combined bacterial infection were also isolated and reported $5(3.05 \%)$ with Staphylococcus spp. + Streptococcus spp., 5 (3.05\%) with Escherichia coli + Streptococcus spp., and 13 $(7.93 \%)$ with Escherichia coli + Staphylococcus spp (Fig. 1-25 and Table 17).

Table.1 Grades of CMT reaction in subclinical mastitis

\begin{tabular}{|c|c|c|c|}
\hline S. No. & $\begin{array}{c}\text { CMT reaction } \\
\text { grade }\end{array}$ & $\begin{array}{c}\text { Number of } \\
\text { quarters showing } \\
\text { CMT reaction }\end{array}$ & $\begin{array}{c}\text { Incidence } \\
(\%)\end{array}$ \\
\hline 1. & - & 366 & 74.39 \\
\hline 2. & + & 40 & 8.13 \\
\hline 3. & ++ & 54 & 10.98 \\
\hline 4. & +++ & 32 & 6.50 \\
\hline 5. & Total & 492 & 100.00 \\
\hline
\end{tabular}

Table.2 Range of somatic cell count in subclinical mastitis

\begin{tabular}{|c|c|c|}
\hline S.No. & Range of SCC & Number of quarters \\
\hline 1. & $<$ lakh & 357 \\
\hline 2. & $1-2$ lakhs & 33 \\
\hline 3. & $2-3$ lakhs & 41 \\
\hline 4. & $3-4$ lakhs & 18 \\
\hline 5. & $4-5$ lakhs & 29 \\
\hline 6. & $5-6$ lakhs & 14 \\
\hline 7. & Total & 492 \\
\hline
\end{tabular}

$(n=492)$ 
Table.3 Bacteria isolated from the quarters affected with subclinical mastitis

\begin{tabular}{|c|c|c|c|c|}
\hline S.No. & Type of bacteria & $\begin{array}{c}\text { Number of } \\
\text { quarters tested }\end{array}$ & $\begin{array}{c}\text { Number of quarters } \\
\text { positive }\end{array}$ & Percentage $(\%)$ \\
\hline 1. & Staphylococcus spp. & 492 & 87 & 53.05 \\
\hline 2. & Streptococcus spp. & 492 & 22 & 13.42 \\
\hline 3. & Escherichia coli & 492 & 28 & 17.07 \\
\hline 4. & Klebsiella spp. & 492 & 4 & 2.44 \\
\hline 5. & Staphylococcus spp. + Streptococcus spp. & 492 & 5 & 3.05 \\
\hline 6. & Escherichia coli + Streptococcus spp. & 492 & 5 & 3.05 \\
\hline 7. & Escherichia coli + Staphylococcus spp. & 492 & 13 & 7.93 \\
\hline 8. & Total & 492 & 164 & 100.01 \\
\hline
\end{tabular}

Table.4 Comparative study on incidence of sub clinical mastitis in cows by CMT, SCC and Cultural isolation

\begin{tabular}{|c|c|c|c|c|c|c|c|}
\hline \multirow{2}{*}{ S.No. } & Name of Test & \multicolumn{3}{|c|}{ No. of animals } & \multicolumn{3}{|c|}{ No. of quarter } \\
\cline { 3 - 7 } & & Tested & Positive & Incidence & Tested & Positive & Incidence \\
\hline 1. & CMT & 123 & 78 & 63.42 & 492 & 126 & 25.61 \\
\hline 2. & SCC & 123 & 82 & 66.67 & 492 & 135 & 27.44 \\
\hline 3. & Cultural isolation & 123 & 91 & 73.98 & 492 & 164 & 33.33 \\
\hline
\end{tabular}

Table.5 Grades of CMT reaction VS status of infection in SCM affected quarters

$(n=492)$

\begin{tabular}{|c|c|c|c|c|c|c|}
\hline \multirow[t]{2}{*}{ S.No } & \multirow{2}{*}{$\begin{array}{c}\text { CMT reaction } \\
\text { grade }\end{array}$} & \multirow{2}{*}{$\begin{array}{c}\text { Number of quarters } \\
\text { showing CMT reaction }\end{array}$} & \multicolumn{4}{|c|}{ No. of quarters } \\
\hline & & & Culturally positive & Per cent & Culturally negative & Per cent \\
\hline 1. & - & 366 & 54 & 14.75 & 312 & 85.25 \\
\hline 2. & + & 40 & 31 & 77.50 & 9 & 22.50 \\
\hline 3. & ++ & 54 & 48 & 88.89 & 6 & 11.11 \\
\hline 4. & +++ & 32 & 31 & 96.86 & 1 & 3.13 \\
\hline 5. & Total & 492 & 164 & 33.33 & 328 & 66.67 \\
\hline
\end{tabular}


Table.6 Somatic cell count VS status of infection in SCM affected quarters

\begin{tabular}{|c|c|c|c|c|c|c|}
\hline \multirow{2}{*}{ S.No } & \multirow{2}{*}{ SCC } & \multirow{2}{*}{$\begin{array}{l}\text { Number of quarters } \\
\text { showing SCC positive }\end{array}$} & \multicolumn{4}{|c|}{ No. of quarters } \\
\hline & & & Culturally positive & Per cent & Culturally negative & Per cent \\
\hline 1. & $<1$ lakh & 357 & 36 & 10.08 & 321 & 89.92 \\
\hline 2. & 1-2 lakhs & 33 & 28 & 84.85 & 5 & 15.15 \\
\hline 3. & 2-3 lakhs & 41 & 39 & 95.12 & 2 & 4.88 \\
\hline 4. & 3-4 lakhs & 18 & 18 & 100.00 & $\mathbf{0}$ & 0.00 \\
\hline 5. & 4-5 lakhs & 29 & 29 & 100.00 & $\mathbf{0}$ & 0.00 \\
\hline 6. & 5-6 lakhs & 14 & 14 & 100.00 & $\mathbf{0}$ & 0.00 \\
\hline 7. & Total & 492 & 164 & 33.33 & 328 & 66.67 \\
\hline
\end{tabular}

Table.7 Percent accuracy of CMT and SCC considering cultural examination as standard for SCM diagnosis

\begin{tabular}{|c|c|c|c|c|c|c|c|c|c|c|c|c|c|}
\hline \multirow[t]{2}{*}{ S.No. } & \multirow{2}{*}{$\begin{array}{c}\text { Name of } \\
\text { the test }\end{array}$} & \multirow{2}{*}{$\begin{array}{c}\text { Total } \\
\text { samples } \\
\text { examined }\end{array}$} & \multirow{2}{*}{$\begin{array}{c}\text { Test } \\
\text { positive } \\
\text { samples }\end{array}$} & \multirow{2}{*}{$\begin{array}{c}\text { Test } \\
\text { negative } \\
\text { samples }\end{array}$} & \multicolumn{9}{|c|}{ Test reaction as compared to cultural examination } \\
\hline & & & & & $\begin{array}{c}\text { True } \\
\text { positive }\end{array}$ & $(\%)$ & $\begin{array}{c}\text { False } \\
\text { positive }\end{array}$ & $(\%)$ & $\begin{array}{c}\text { True } \\
\text { negative }\end{array}$ & $(\%)$ & $\begin{array}{c}\text { False } \\
\text { negative }\end{array}$ & $(\%)$ & $\begin{array}{l}\text { Per cent } \\
\text { accuracy }\end{array}$ \\
\hline 1. & CMT & 492 & 126 & 366 & 110 & 87.30 & 16 & 12.70 & 312 & 85.25 & 54 & 14.75 & 85.77 \\
\hline 2. & SCC & 492 & 135 & 357 & 120 & 88.89 & 15 & 11.11 & 321 & 89.92 & 36 & 10.08 & 89.63 \\
\hline \multirow[t]{4}{*}{3.} & $\begin{array}{l}\text { Cultural } \\
\text { isolation }\end{array}$ & 492 & 164 & 328 & 164 & 100.00 & $\mathbf{0}$ & 0.00 & 328 & 100.00 & $\mathbf{0}$ & 0.00 & 100.00 \\
\hline & & & \multicolumn{2}{|c|}{$\%$ Accuracy $=$} & Numb & er of true & $\frac{\text { positive an }}{\text { Numbe }}$ & $\frac{\text { nals }+1}{\text { f samp }}$ & umber of $t$ & ue negat & ve animals & $\underline{x} 100$ & \\
\hline & & & \multicolumn{2}{|c|}{$\%$ False positive } & & $=$ & \multicolumn{4}{|c|}{ Number of false positive samples $\times 100$} & & & \\
\hline & & & \multicolumn{2}{|c|}{$\%$ False negative } & & $=$ & \multicolumn{4}{|c|}{$\frac{\text { Number of false negative samples }}{\text { Number of samples negative by test }}$} & & & \\
\hline
\end{tabular}


Table.8 Sensitivity, specificity and predictive value of CMT and SCC considering cultural examination as standard for SCM diagnosis

\begin{tabular}{|c|c|c|c|c|}
\hline S.No. & $\begin{array}{c}\text { Name of the } \\
\text { test }\end{array}$ & Sensitivity & Specificity & $\begin{array}{c}\text { Predictive value } \\
\text { of positive test }\end{array}$ \\
\hline 1. & CMT & 67.07 & 95.12 & 87.30 \\
\hline 2. & SCC & 76.92 & 95.54 & 88.89 \\
\hline 3. & $\begin{array}{c}\text { Cultural } \\
\text { isolation }\end{array}$ & 100.00 & 100.00 & 100.00 \\
\hline
\end{tabular}

Sensitivity $=a /(a+c) \times 100$

Specificity $=\mathrm{d} /(\mathrm{b}+\mathrm{d}) \times 100$

Predictive value for + ve test $=\mathrm{a} /(\mathrm{a}+\mathrm{b}) \times 10$

$\mathrm{a}=$ Disease positive and test positive (true positive)

$\mathrm{b}=$ Disease negative but test positive (false positive)

$\mathrm{c}=$ Disease positive but test negative (false negative)

$\mathrm{d}=$ Disease negative and test negative (true negative)

Fig.1 Grades of CMT reaction in subclinical mastitis

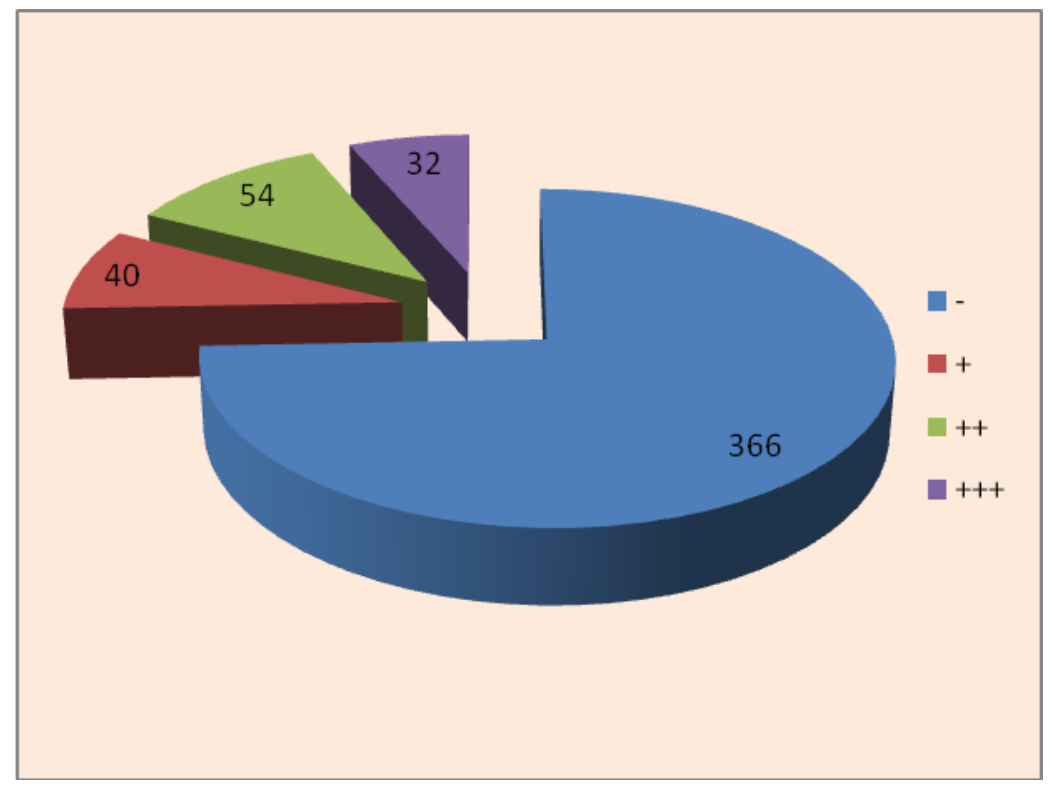


Fig.2 Milk sample with CMT positive and negative reactions

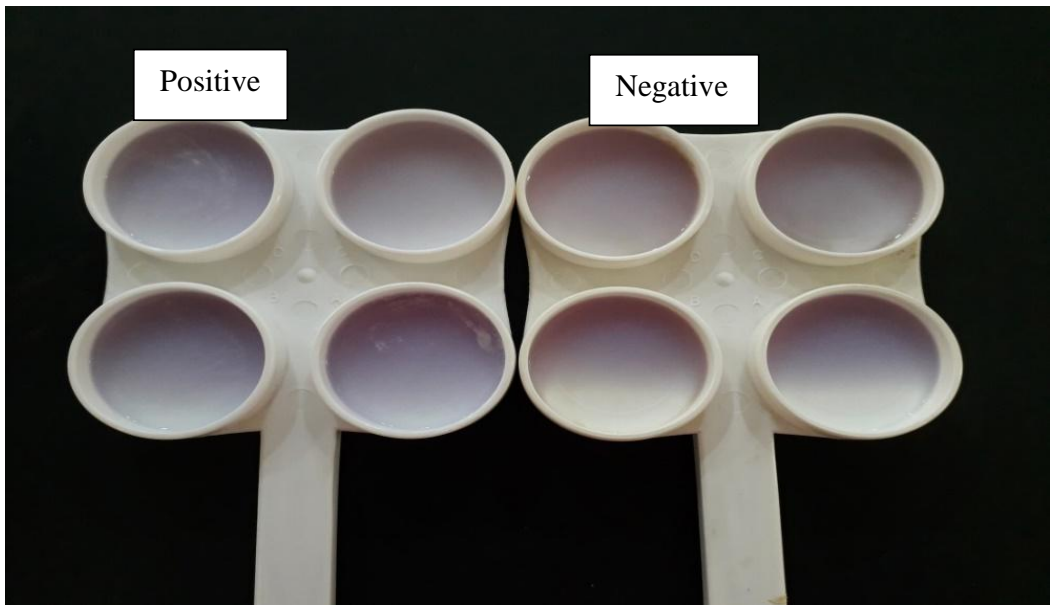

Fig.3 Range of somatic cell count in subclinical mastitis

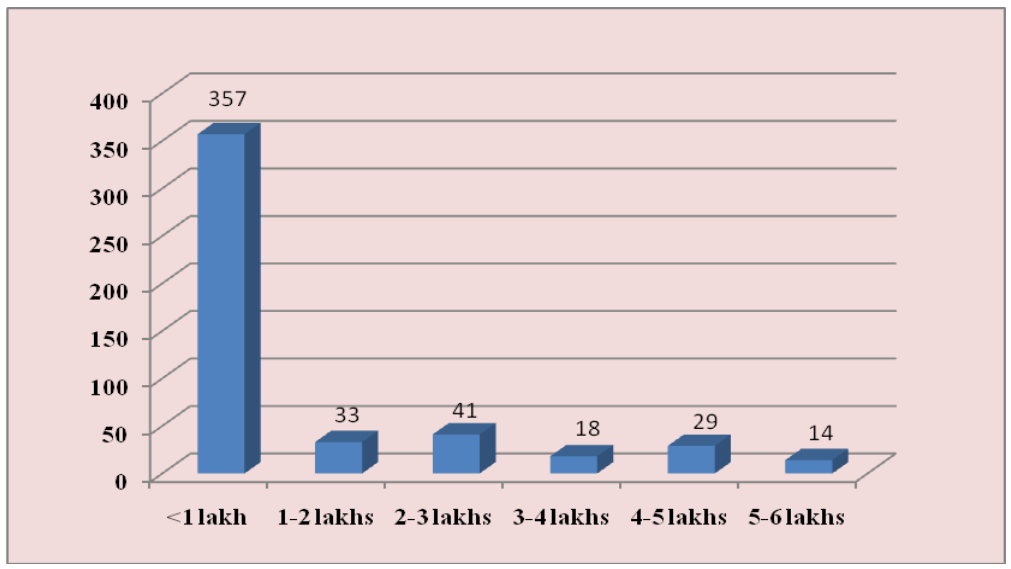

Fig.4 Bacteria isolated from the quarters affected with subclinical mastitis

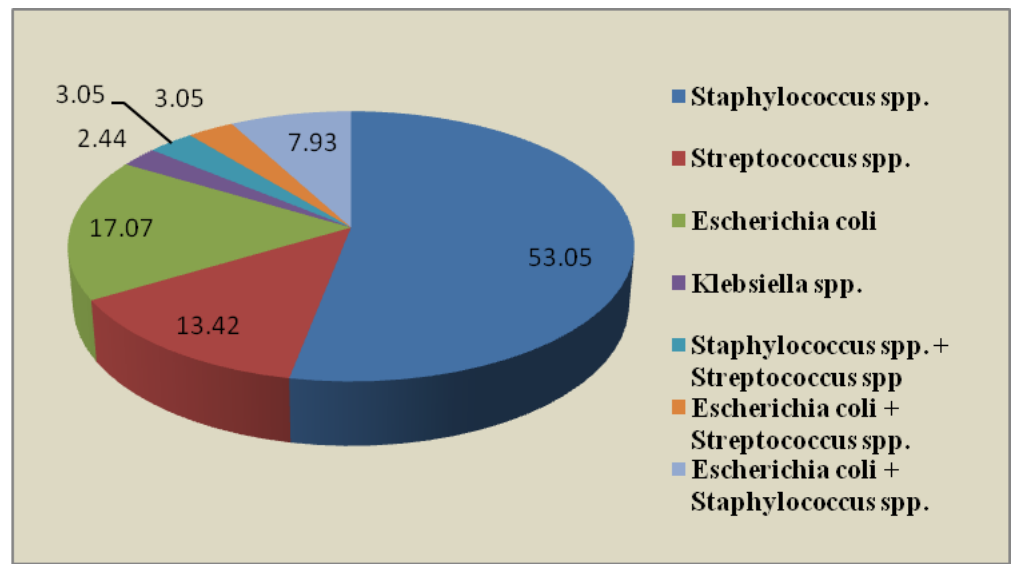


Fig.5 Staphylococcus spp. showing golden pigmentation on MSA

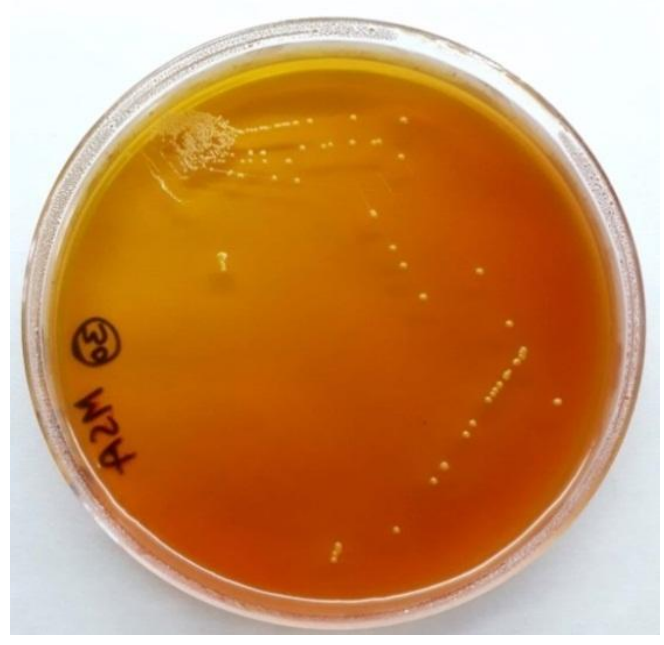

Fig.7 Staphylococcus spp. colonies on BHI agar

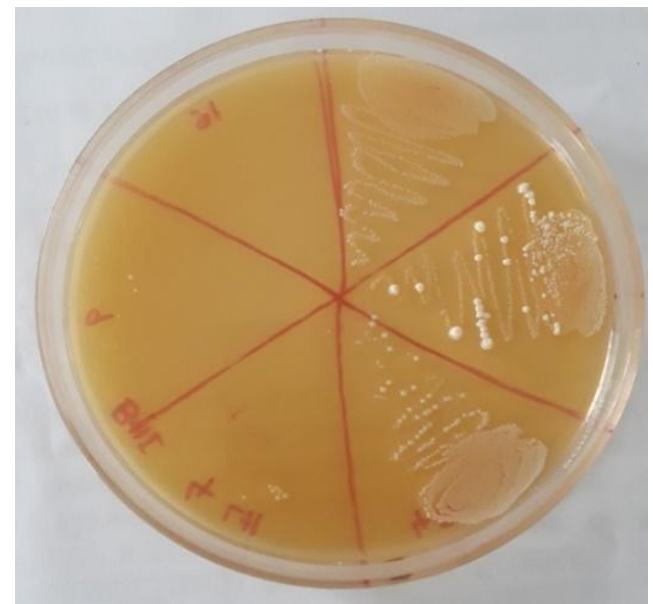

Fig.9 Microscopic view of staphylococcus spp. with Gram's staining

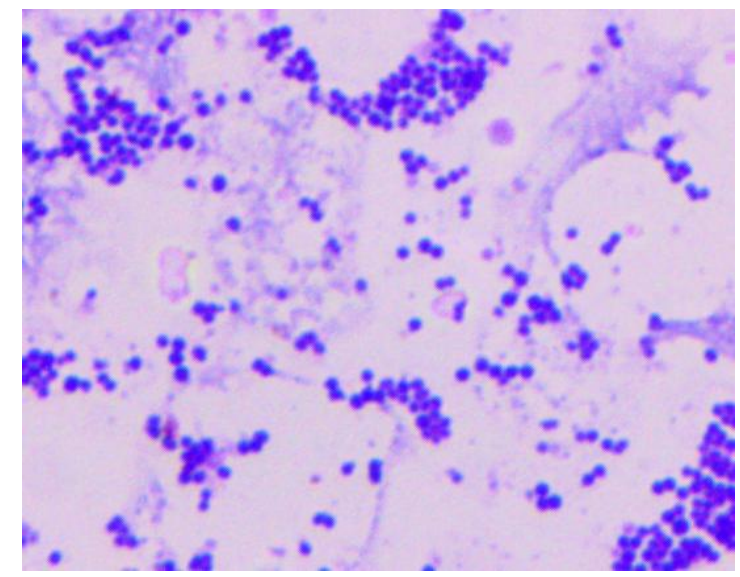

Fig.6 Staphylococcus spp. showing golden yellow and pink pigmentation on MSA

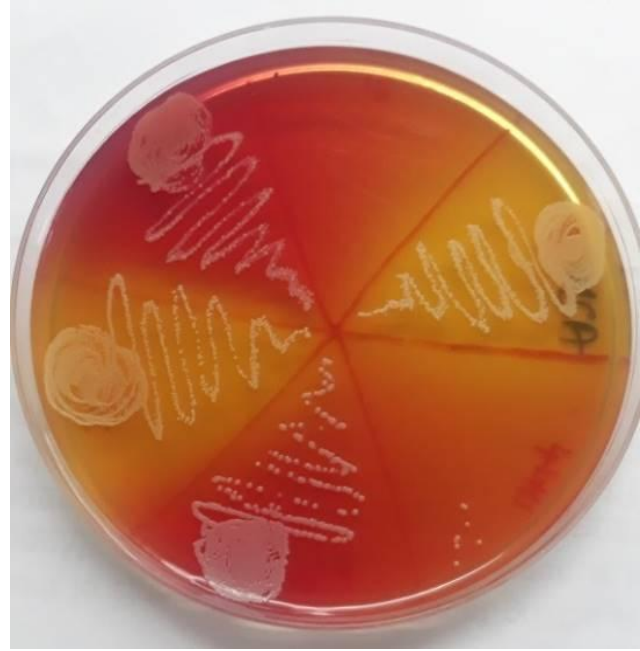

Fig.8 Catalase positive reaction of staphylococcus spp

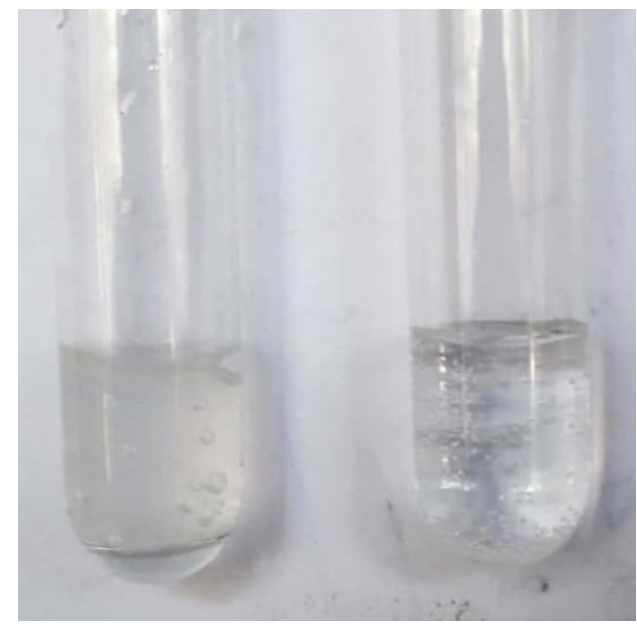

Fig.10 Small pin point transparent Streptococcus spp. colonies on Nutrient agar

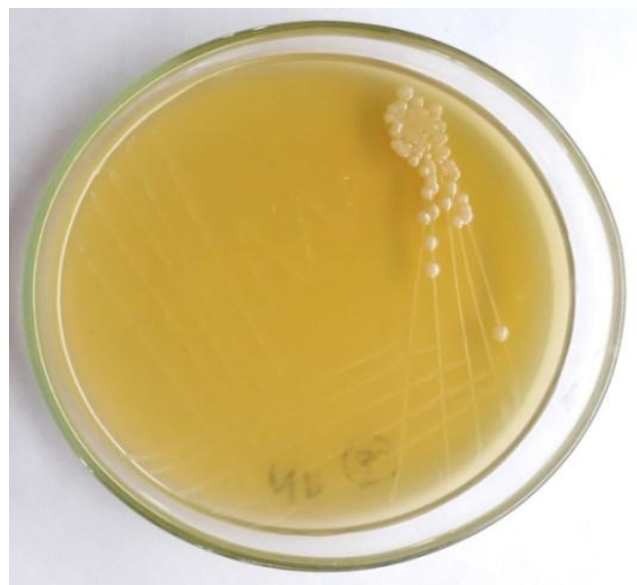


Fig.11 Small pin point hemolytic Streptococcus spp. colonies on blood agar

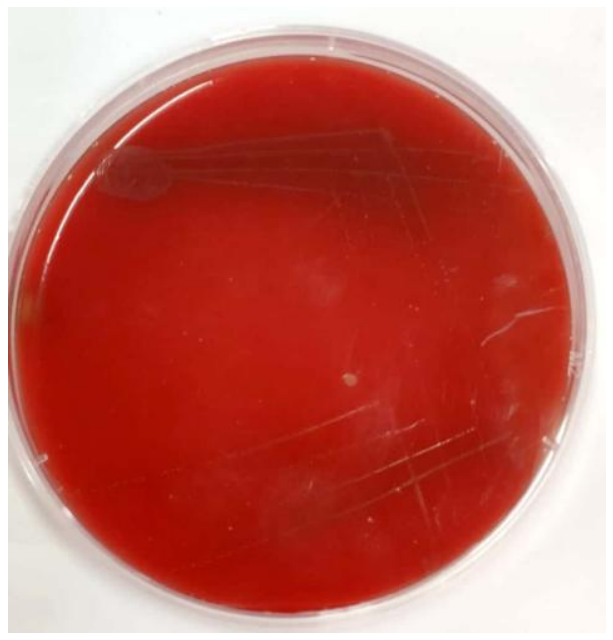

Fig.13 Smear showing Streptococcus spp. chains with Gram's staining

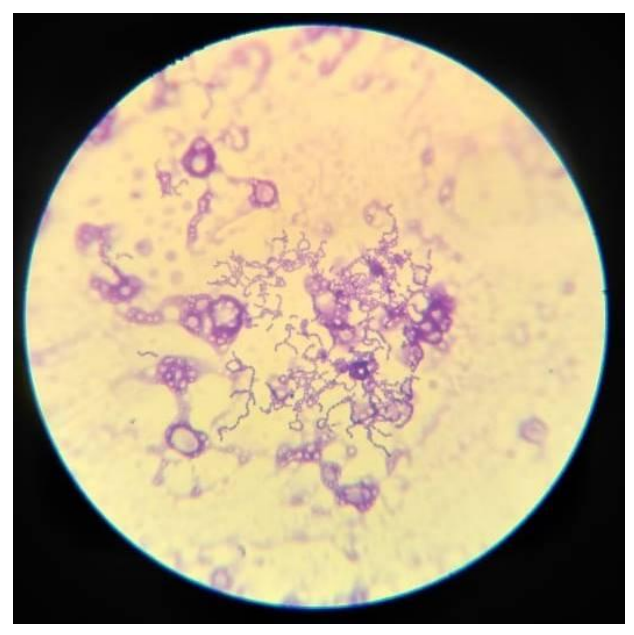

Fig.12 Small pinpoint Streptococcus spp. colonies on Edward's agar

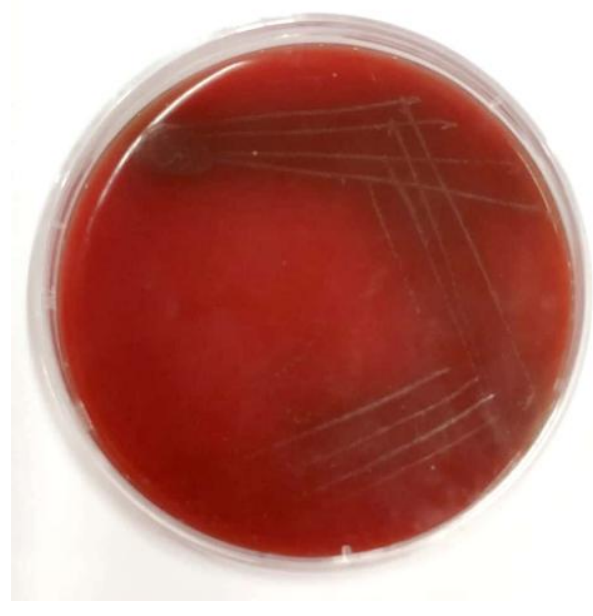

Fig.14 E. coli showing green metallic sheen on EMB Agar

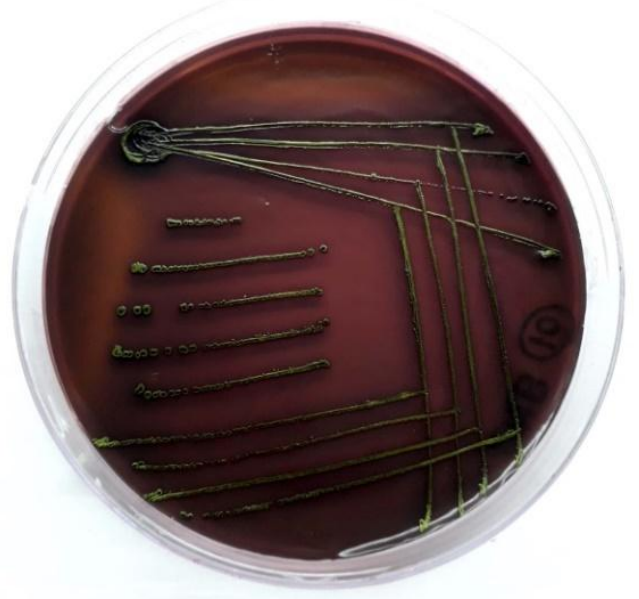


Fig.15 Oval shaped E. coli organisms with Gram's staining

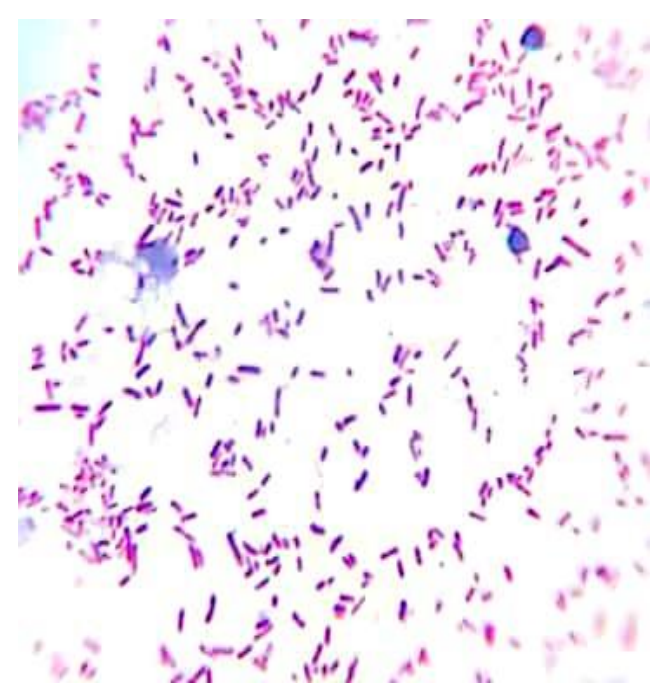

Fig.16 IMVCN reaction of E. coli.

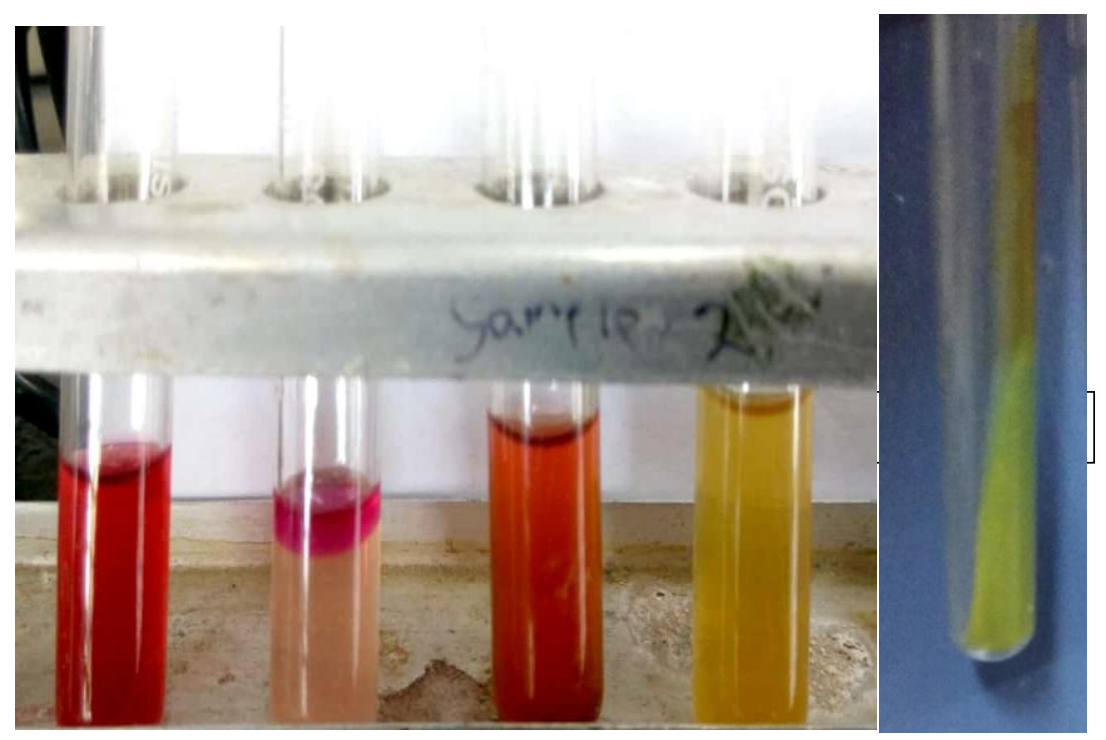


Fig.17 Capsulated large and mucoid Klebsiella spp. colonies on MacConkey agar

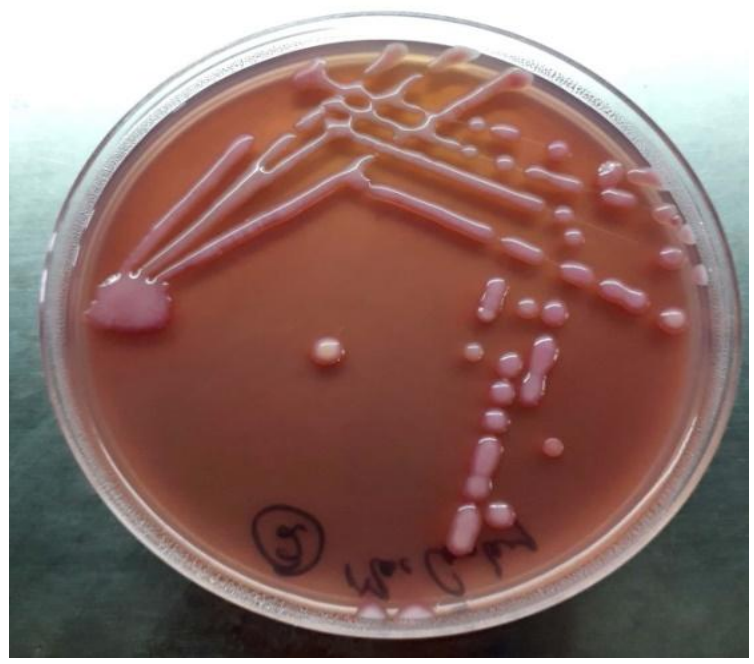

Fig.18 Pink color paired rod shaped Klebsiella spp. organism with gram's stain

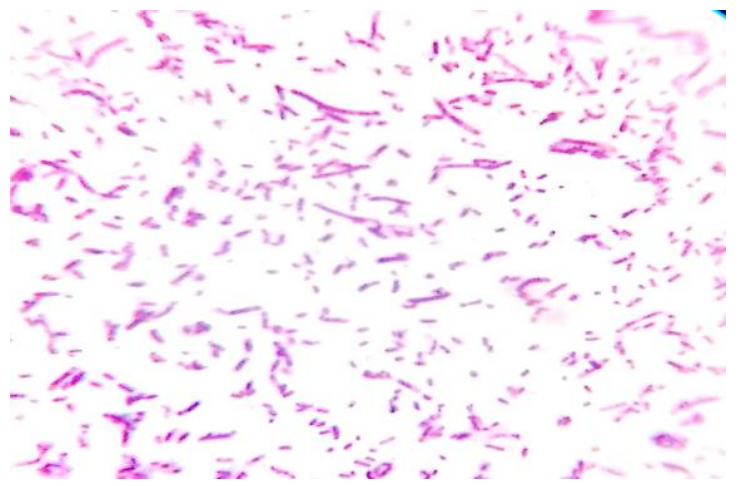

Fig.19 IMVCN reaction of Klebsiella spp.

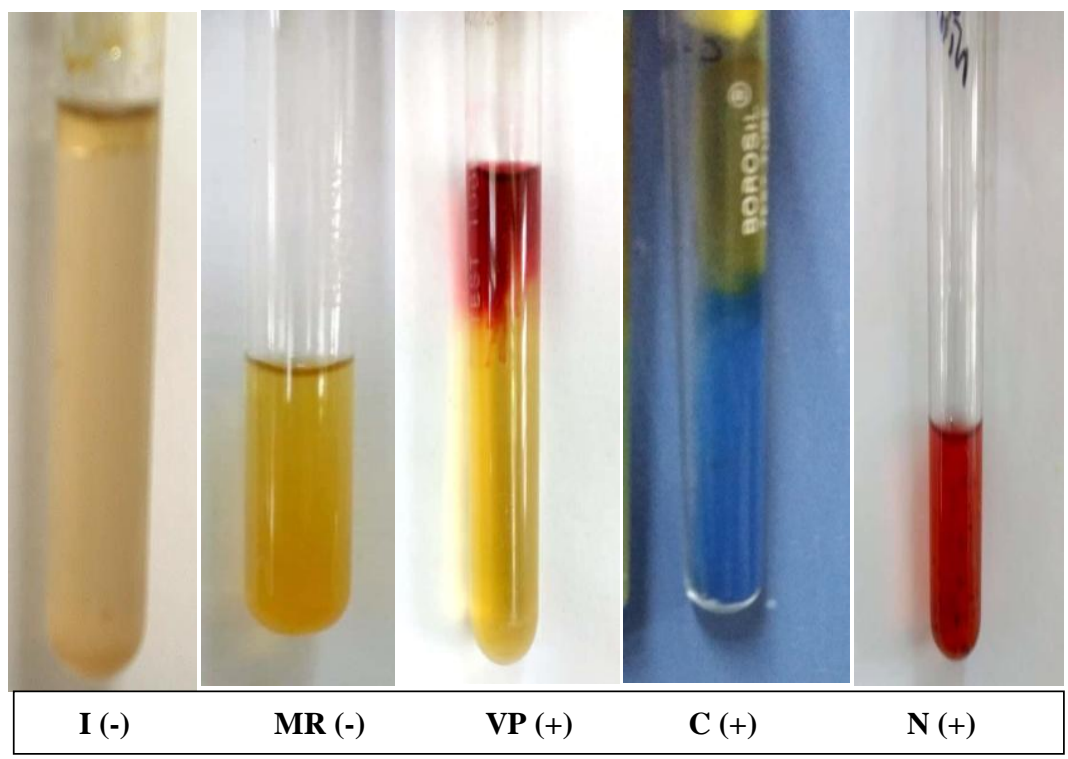


Fig.20 Animal wise Comparative study on the incidence of subclinical mastitis in crossbred cows by CMT, SCC and Cultural isolation

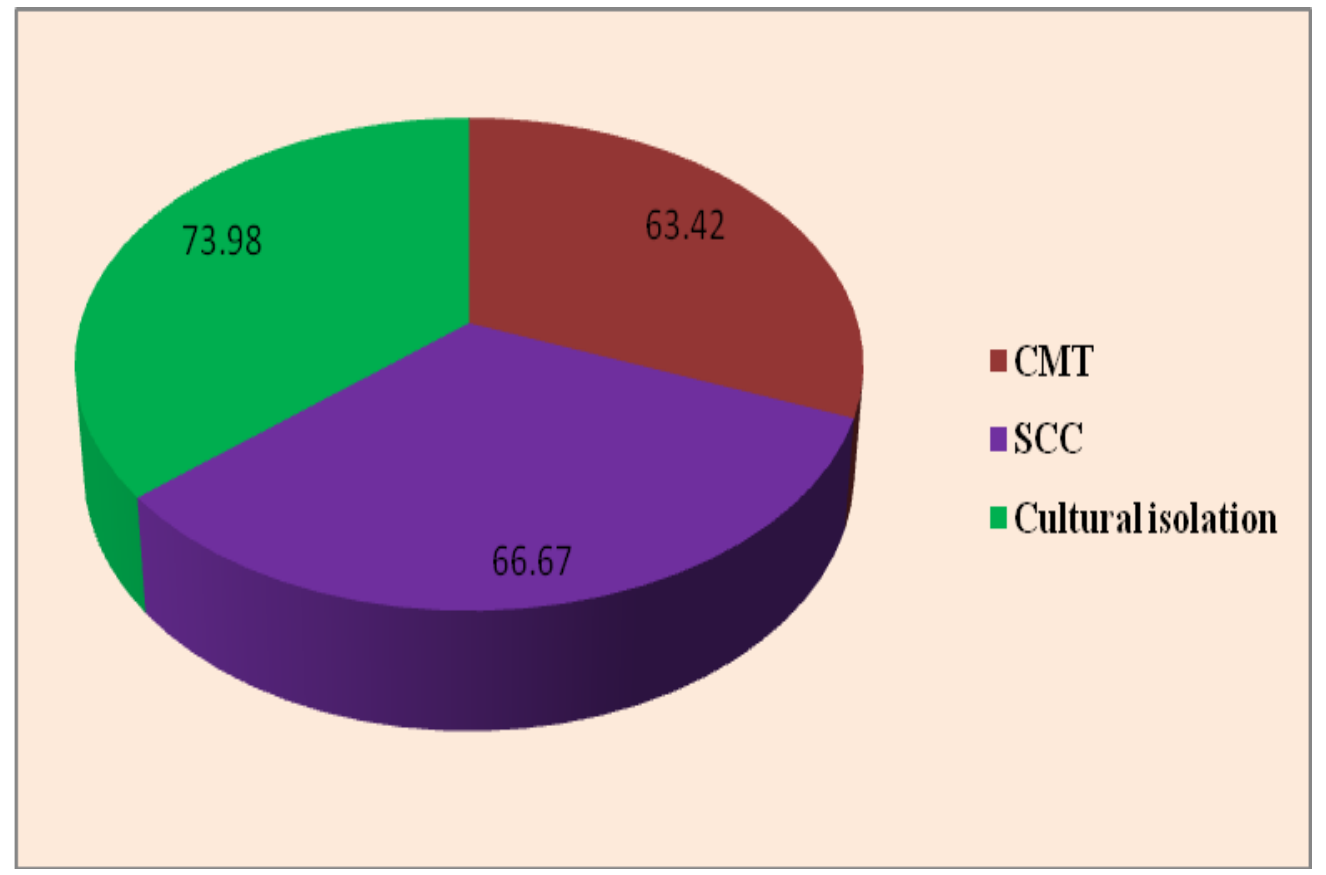

Fig.21 Quarter wise Comparative study on the incidence of subclinical mastitis in crossbred cows by CMT, SCC and Cultural isolation

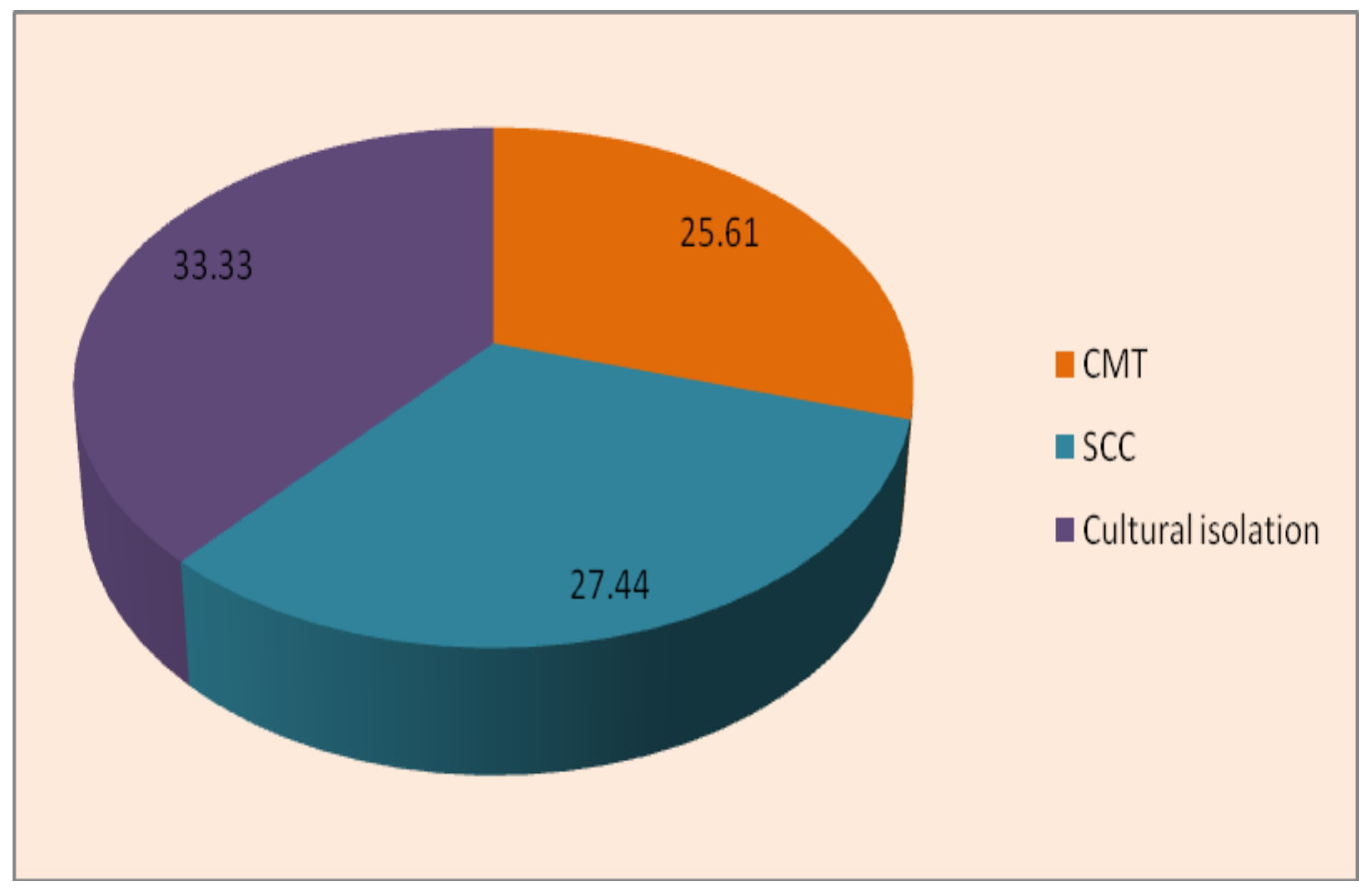


Fig.22 Grades of CMT reaction VS status of infection in SCM affected quarters

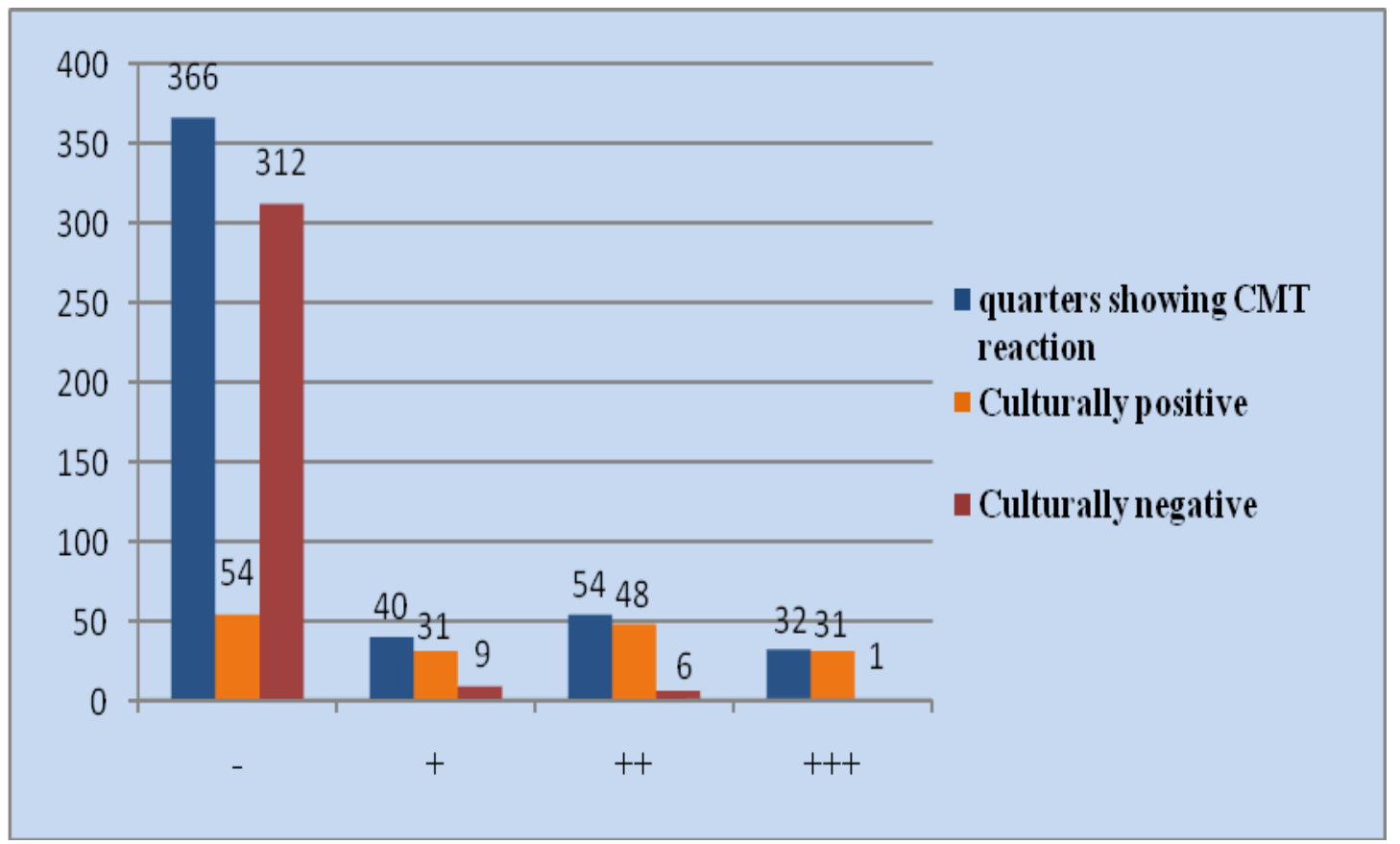

Fig.23 Somatic cell count VS status of infection in SCM affected quarters

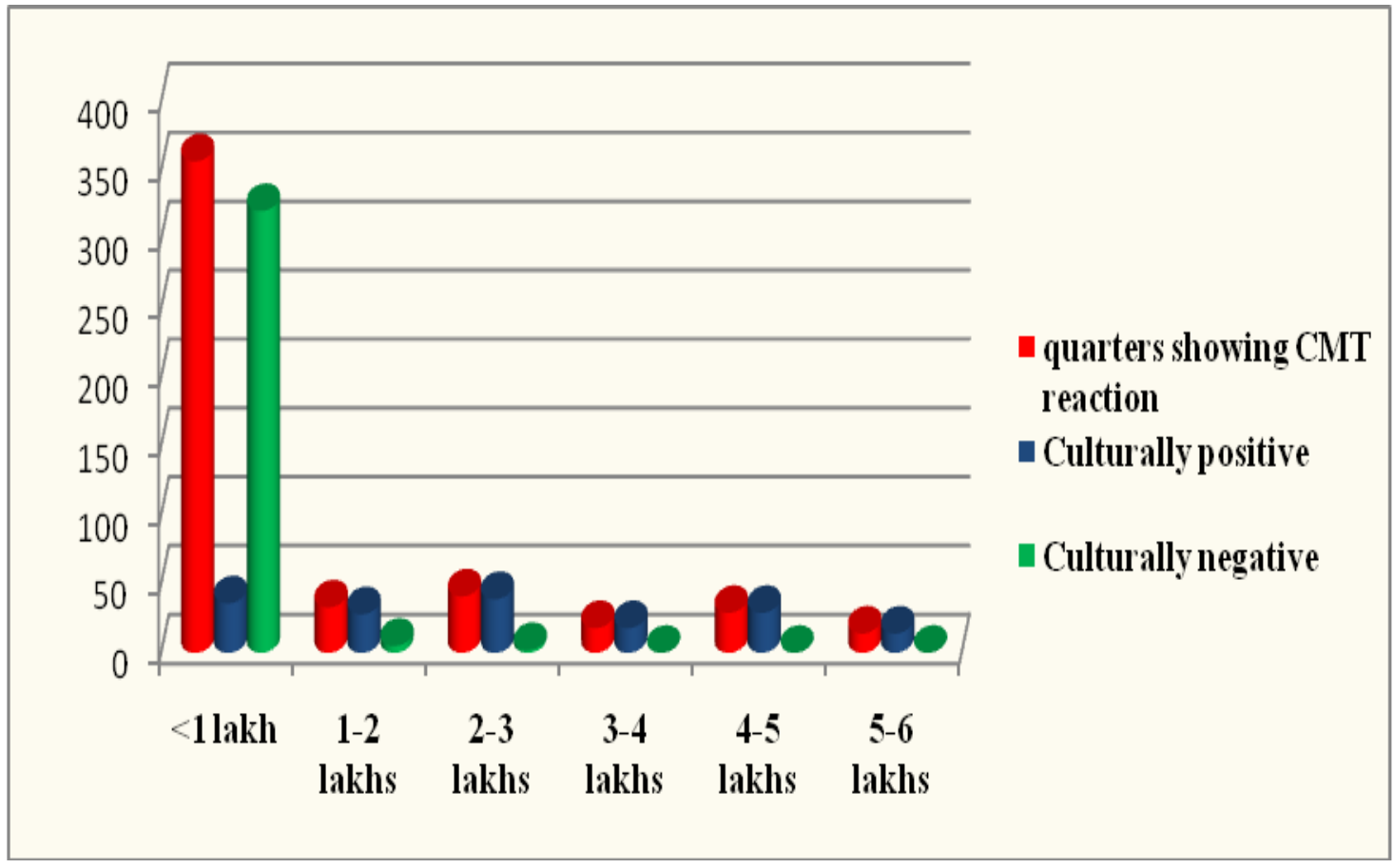


Fig.24 Percent accuracy of CMT and SCC considering cultural examination as standard for SCM diagnosis

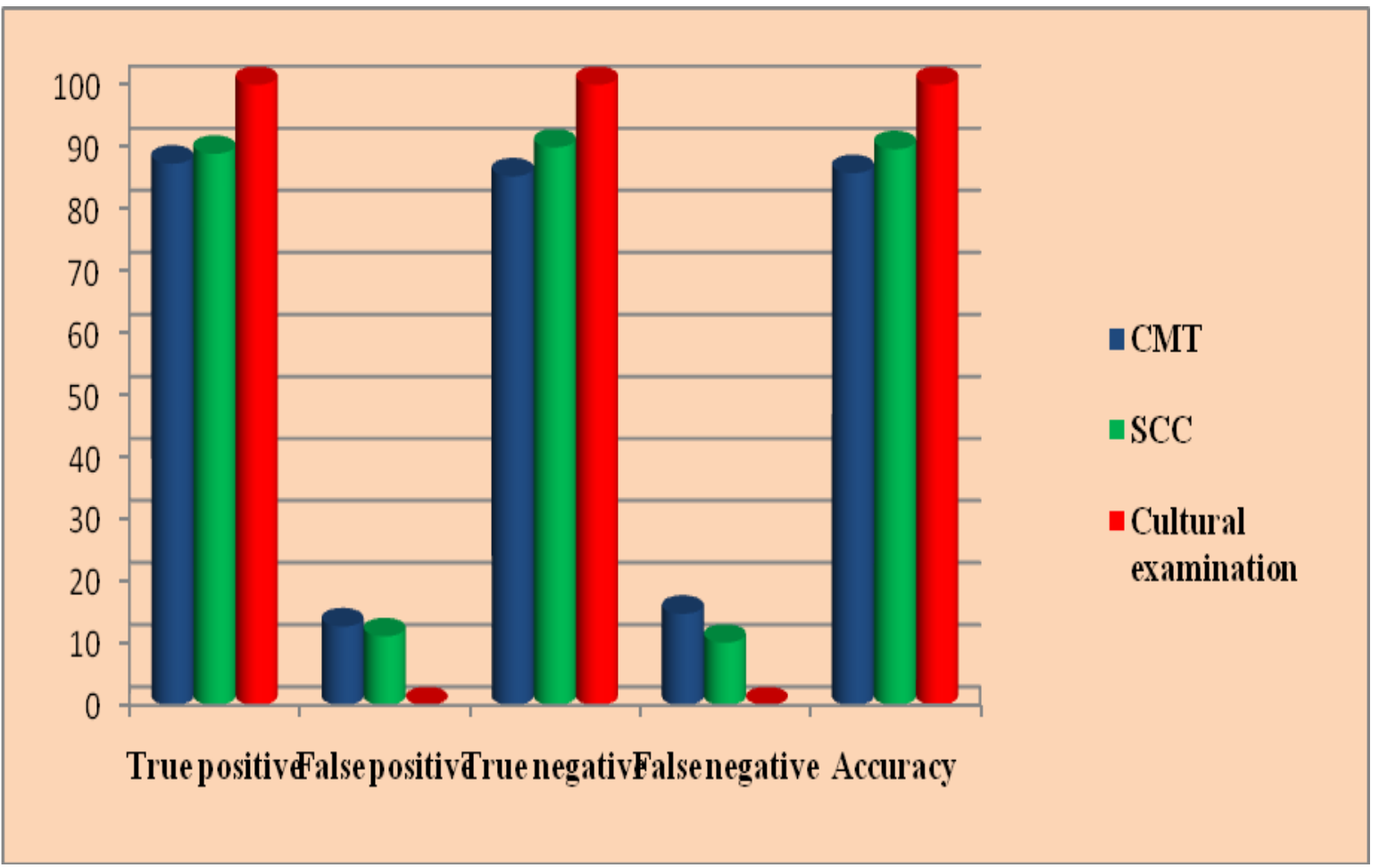

Fig.25 Sensitivity, specificity and predictive value of CMT and SCC considering cultural examination as standard for SCM diagnosis

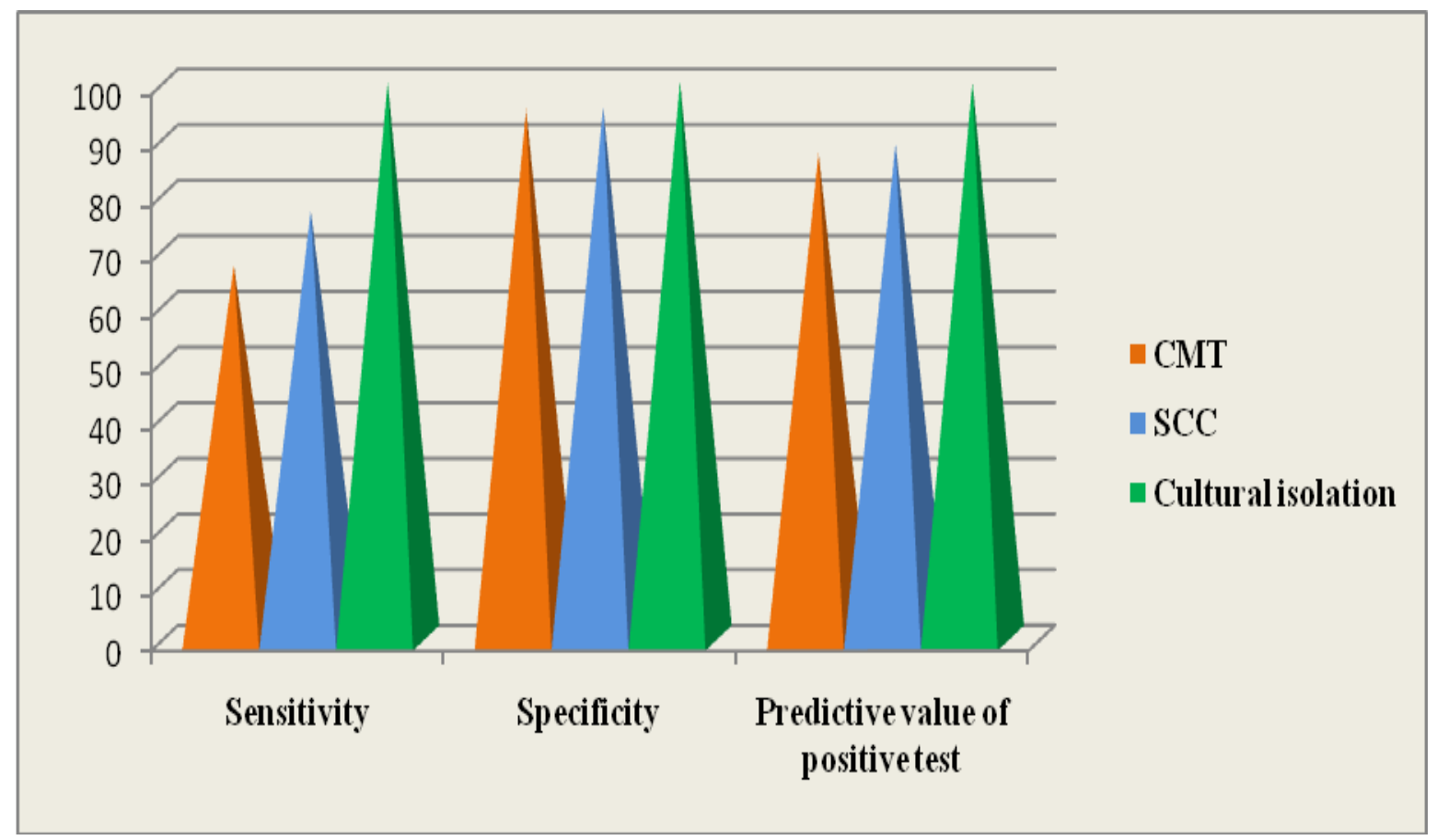


However, Khanal and Pandit (2013) reported Streptococcal mastitis as the commonest $(11.1 \%)$ followed by coliform $(9.5 \%)$ and staphylococcal (7.9\%). Whereas Saidi et al., (2013) reported most prevalent organism for SCM as Staphylococcus aureus (40\%) followed by Streptococcus spp. (12.5\%), Enterobacteriaceae (2.5\%), Pseudomonas spp. (2.5\%), Staphylococcus aureus + Streptococcus spp. (12.5\%), Streptococcus spp.+ Escherichia coli (7.5\%), S. aureus + Mycoplasma spp.(7.5\%), and S. aureus + Streptococcus spp.+ E. coli (5\%). Krishnamoorthy et al., (2017) documented $45 \%, 13 \%$ and $14 \%$ of prevalence of sub clinical mastitis by Staphylococcus sp., Streptococcus spp. and Escherichia coli, respectively. Malek et al., (2011) stated that the prevalence of minor pathogens was higher (31.9\%) than that of major pathogens (17.8\%) in sub clinical mastitis and isolated Corynebacterium spp. (17.7\%), Staphylococcus aureus (15.3\%), coagulase negative Staphylococcus (CNS) (14.3\%), Streptococcus uberis (1.9\%) and Streptococcus dysgalactiae (0.6\%). Mir et al., (2014) in their investigation isolated Staphylococci $(41.04 \%)$ in specific subclinical mastitis as the main organisms, while in case of latent infections Corynebacteria (36.81\%) were found to be chief isolates. Highest prevalence of $E$. coli in cultural examination of present investigation could be due to improper hygienic management practices in farms leading to contamination of feed, water and milking machines which were found to be factors for high incidence of SCM by environmental pathogens.

\section{Comparative study of CMT, SCC and} cultural examination

In the present investigation, animal wise incidence with respect to $\mathrm{CMT}, \mathrm{SCC}$ and cultural examination was $63.42 \%, 66.67 \%$ and $73.98 \%$, respectively, whereas quarter wise incidence was $25.61 \%, 27.44 \%$ and $33.33 \%$, respectively. Similar findings of animal-wise incidence of SCM were recorded as $72.07 \%$, $66.67 \%$ by CMT and SCC, respectively and quarter-wise incidence as $59.68 \%, 51.80 \%$ by CMT and SCC, respectively by Badiuzzaman et al., (2015). While Biswadeep et al., (2015) carried out a cross sectional study on lactating cows of Jaipur district for SCM by using CMT and SCC and recorded prevalence of 67.27 and $74.55 \%$ respectively.

Out 492 quarter milk samples, 366 were negative for CMT and remaining samples of 40, 54 and 32 were found positive with $1+, 2+$ and $3+$ reactions, respectively. Among the CMT negative and positive with $1+, 2+$ and $3+$ reactions, the culturally positive samples were 54 (14.75\%), 31 (77.50\%), 48 (88.89\%) and 31 (96.86\%), respectively. Among 492 quarter milk samples 357, 33, 41, 18, 29 and 14 samples showed SCC of <1 lakh, 1-2 lakhs, 2-3 lakhs, 3-4 lakhs, 4-5 lakhs and 5-6 lakhs, respectively and among these culturally positive were 36 (10.08), 28 (84.85), 39 (95.12), 18 (100.00), 29 (100.00) and 14 (100.00), respectively. Reason for false positive cases of sub clinical mastitis by CMT and SCC during early lactation could be because of increases in somatic cell count even without intra mammary infection.

In present investigation, the percent accuracy, false positive and false negative results for SCM diagnosis with CMT and SCC considering cultural examination as standard were recorded as 85.77 and 89.63, 12.70 and 11.11 and 14.75 and 10.08 percent, respectively. Whereas, Sensitivity, specificity and predictive value of positive test of CMT and SCC for the detection of SCM considering cultural examination as standard were recorded as 67.07 and 76.92, 95.12 and 95.54 and 87.30 and 88.89 percent, respectively. Present findings are in accordance with Salvador et al., (2012) who calculated the true prevalence of sub clinical mastitis with the $82.4 \%$ sensitivity and $80.6 \%$ specificity by 
CMT. Present findings are in accordance with Hoque et al., (2015) who screened SCM in lactating cows with CMT and SCC and reported the sensitivity, specificity, percentage accuracy and positive predictive value of 65.8 and 82.5, 76.2 and 89.4, 70.0 and 85.2 and 75.2 and 92.7 percent, respectively. Similarly, Badiuzzaman et al., (2015) also recorded the sensitivity, specificity, percentage accuracy, positive predictive value and negative predictive values for CMT and SCC taking cultural examination as standard as $80.08 \%$ and $86.60 \%, 69.40 \%$ and $97.81 \%, 75.68 \%$ and $91.22 \%, 78.87 \%$ and $98.26 \%$ and $70.95 \%$ and $83.64 \%$, respectively. Whereas, Sharma et al., (2010) recorded the sensitivity of $86.07 \%$, $74.63 \%$ and $88.60 \%$, specificity of $59.70 \%$, $17.16 \%$ and $97.76 \%$, percentage accuracy of $75.52 \%, 51.64 \%$ and $91.94 \%$, positive predictive value of $76.21 \%, 57.47 \%$ and $98.33 \%$ and negative predictive value of $74.07 \%, 31.08 \%$ and $84.52 \%$, respectively for CMT, SLST and SCC, respectively taking cultural examination as standard.

\section{References}

Biswadeep, J., Kumar, P. N., Abhishek, S. and Abrar, A. (2015). Subclinical bovine mastitis in rural, peri urban and suburban regions of Jaipur district of Rajasthan. Indian Journal of Animal Research 5(1): 175-182.

Buchanan, R. E. and Gibbons, N. E. (1974). Bergy's manual of determinations bacteriology, 8th Edn. The Williams and Wilkims Company Boltimore, USA.

Contreras, G. A. and Rodríguez, J. M., Mastitis: comparative etiology and epidemiology. (2011). J. Mammary Gland Biol. Neoplasia, 339-356.

Cruickshank, R., Duguid, J. P., Marmoin, B. P. and Swain, R. H. A. (1975). Medical Microbiology, Volume II, 12th Edn. Churchill Livington,
Edinburgh, London and New York.

Dingwell, R. T., Leslie, K. E., Schukken, Y. H., Sargeant, J. M., Timms, L. L. (2003). Evaluation of the California mastitis test to detect an intramammary infection with a major pathogen in early lactation dairy cows. Can. Vet. J.; 44: 413-416.

Grohn, Y. T., Eicker, S. W. and Hertl, J. A. (1995). The association between previous 305-day milk yield and disease in New York state dairy cows. J. Dairy Sci. 78:1693-1702.

Hadrich, C. A., Wolf, J., Lombard and Dolakg, T. M. (2018).Estimating milk yield and value losses from increased somatic cell count on US dairy farms. J. C. J. Dairy Sci. 101:3588-3596.

Halasa, T., Huijps, K., Qsteras, O. and Hogeveen, H. (2007). Economic effects of bovine mastitis and mastitis management: A review. Vet. Q. 29:1831.

Hoque, M. N., Das, Z. C., Talukder, A. K., Alam, M. S. and Rahman, A. N. M. A. (2015). Different screening tests and milk somatic cell count for the prevalence of subclinical bovine mastitis in Bangladesh. Trop Anim Health Prod. 47(1): 79-86.

Kasikci, G., Cetin, O., Bingol, E. B., Gunduz, M. C. (2012). Relations between electrical conductivity, somatic cell count, California mastitis test and some quality parameters in the diagnosis of subclinical mastitis in dairy cows, Turk. J. Vet. Anim. Sci. 36(1): 49-55.

Khanal, T. and Pandit, A. (2013). Assessment of sub-clinical mastitis and its associated risk factors in dairy livestock of Lamjung, Nepal. Int. J. Infect Microbiol: 2 (2): 49-54.

Krishnamoorthy, P., Suresh, K. P., Saha, S., Govindaraj, G., Shome, B. R. and Parimal R. (2017). Meta-analysis of 
Prevalence of Subclinical and Clinical Mastitis, Major Mastitis Pathogens in Dairy Cattle in India. Int. J. Curr. Microbiol. App. Sci 6(3): 1214-1234.

Malek, D. R. C. B., Barreiro, J. R., Moreno, J. F. G., Porcionato, M. A. F. and Santos, M. V. (2011). Evaluation of somatic cell count thresholds to detect subclinical mastitis in Gyr cows. J. Dairy Sci. 94:4406-4412.

Midleton, J. R., Hardin, D., Steevens, B., Randle, R., Tyler, J. W. (2004). Use of somatic cell counts and California mastitis test results from individual quarter milk samples to detect subclinical intramammary infection in dairy cattle from a herd with a high bulk tank somatic cell count. JAVMA, 224: 419-423.

Mir, A. Q., Bansal, B. K., Gupta, D. K. (2014). Subclinical mastitis in machine milked dairy farms in Punjab: prevalence, distribution of bacteria and current antibiogram. Veterinary Worl. Vol. 7 Issue 5, p291-294. 4p.

Quinn, P. J., Carter, M. E., Markey, B. K. and Carter, G. R. (1999). Veterinary Microbiology, Mosby. Harcourt Publishers Limited, Europe.

Robinson, T. C., Jackson, E. R. and Marr, A. (1988). Mastitis incidence in quarters with different infection status at drying off and calving in two treatment groups. British Veterinary Journal. 144: 166-173.
Saidi, R., Khelef, D. and Kaidi, R. (2013). Subclinical mastitis in cattle in Algeria: Frequency of occurrence and bacteriological isolates. Journal of the South African Veterinary Association 84(1).

Salvador, R. T., Beltran, J. M. C., Abes, N. S., Gutierrez, C. A. and Mingala, C. N. (2012). Short communication: Prevalence and risk factors of subclinical mastitis as determined by the California Mastitis Test in water buffaloes (Bubalis bubalis) in Nueva Ecija, Philippines. J. Dairy Sci. 9 5: 1363-1366.

Schalm, O. W. and Noorlander, D. C. (1957). Experiments and observations leading to the development of California mastitis test. Journal of American Veterinary Medical Association 130:199-204.

Sharma, V. K. and Rajani, H. B. (1969). California mastitis test. Indian Veterinary Journal 46:749-752.

Sharma, N., Pandey, V. and Sudhan, N. A. (2010). Comparison of some indirect screening tests for detection of subclinical mastitis in dairy cows. Bulgarian Journal of Veterinary Medicine, 13(2), 98-103.

Skrzypek, R., Wojtowski, J., Fahr, R. D. (2004). Factors affecting somatic cell count in cow bulk tank milk-a case study from Poland. J. Vet. Med. Series A, 51: 127-131.

\section{How to cite this article:}

Aruna Maramulla, Ambica Gadige, Lakshmi Kosapati, Swathi Bommu, Padmaja Katta and Ramesh Keshamoni. 2019. Cow Side and Laboratory Tests for Diagnosis of Subclinical Mastitis in Cows. Int.J.Curr.Microbiol.App.Sci. 8(11): 2187-2205. doi: https://doi.org/10.20546/ijcmas.2019.811.254 